\title{
THE ACTIONS OF TETRODOTOXIN, PROCAINE, AND ACETYLCHOLINE ON GUSTATORY RECEPTIONS IN FROG AND RAT
}

\author{
Masahiro Ozeki* and Akinori NomA \\ Department of Physiology, Kumamoto University Medical School, Kumamoto 860, Japan
}

Summary 1) The effects of tetrodotoxin (TTX), procaine and acetylcholine $(\mathrm{ACh})$ were investigated both the recording the receptor potential in gustatory cells by measuring and the integrated response of their afferent nerves in rats and frogs.

3) TTX $\left(10^{-6} \mathrm{~g} / \mathrm{ml}\right)$ did not induce electrical responses in the gustatory cells of frog and rat or in chorda tympani nerve of rat and glossopharyngeal nerve of frog, nor did it suppress the generation of the receptor potential in response to gustatory stimuli. Procaine $(0.1$ or $0.5 \%)$ also had no effect on the receptive process in the rat. However, in the frog the magnitude of the integrated response of the nerve in response to $\mathrm{NaCl}$ and $\mathrm{CaCl}_{2}$ was depressed after the tongue had been soaked in TTX.

3) ACh $\left(10^{-4} \mathrm{~g} / \mathrm{ml}\right)$ did not elicit electrical response in the gustatory cell and the nerve of the rat. In the frog, $10^{-3} \mathrm{~g} / \mathrm{ml} \mathrm{ACh} \mathrm{did} \mathrm{not} \mathrm{pro-}$ duce any immediate response in gustatory cell but the magnitude of integrated response of the nerve to $\mathrm{NaCl}$ was modified after the tongue had been soaked in ACh for some time.

4) It was suggested that the penetration of solutions from the tongue surface might hardly occur into the space surrounding the gustatory cell bodies of the rat, while in the frog occur in some extent.

It is well known that tetrodotoxin (TTX) is a powerful poison which selectively blocks sodium activation in excitable cells (NARAHASHI et al., 1964) while not affecting the action of chemical transmitters on post-junctional membrane, as demonstrated, in amphibian and crustacean muscles (FurUKAWA et al., 1959; OzeKi et al., 1966). Recently, KATSUKi, HASHIMOTO, and YANAGISAWA (1970), and Katsuki, Hashimoto, and Kendal (1971) have also reported

Received for publication February 14, 1972

*Present address: Department of Biology, Faculty of Education, Yamanashi University, Kofu 400, Japan

尾関正寬，野間昭典 
that TTX suppresses chemoreception of monovalent cations in the lateralline organ of mullet and catfish, while in the same organ of Xenopus TTX did not suppress the responses to a solution of cations (ONODA and KATSUKI, 1972). It has not yet been examined, however, whether TTX has any action on the gustatory receptive process.

The gustatory receptive process has been studied either by recording integrated responses from the afferent nerve or by recording the receptor potential from the receptor element. Both methods present their particular advantages and disadvantages.

In analyzing the effects of TTX and acetylcholine (ACh) on gustatory responses of different species of animals, some conflicting data were encountered in a preliminary work. Therefore, we decided to apply both methods in order to differentiate the actual site of action of these agents in the gustatory receptive process. It will be shown that the species difference of the effects of TTX and of $\mathrm{ACh}$ on the gustatory response can be ascribed to the different sites of action and also that the different sites have structural correlates in the receptors in different animal species. The action of procaine was also studied and its effect was compared with that of TTX.

\section{MATERIALS AND METHODS}

Frogs, Rana catesbiana and Rana nigromaculata, and adult female rats of the Sprague-Dawley strain were used.

Experiments on rats. A rat, anesthetized with an intravenous tail injection of sodium amobarbitone, was fixed on a stereotaxic table with a head holder and the trachea was cannulated. Procedures employed in inserting microelectrodes into the gustatory cell were the same as those described elsewhere (OzEKI and SATO, 1972). Methods used for recording impulses from the chorda tympani were the same as that described by YAMASHITA and SATO (1965). The amplitudes of integrated nerve responses were measured $10 \mathrm{sec}$ after the application of stimulus. $\mathrm{NaCl}$ of $0.3 \mathrm{M}$, sucrose of $0.5 \mathrm{M}, \mathrm{HCl}$ of $0.01 \mathrm{~N}$, and quinine- $\mathrm{HCl}$ of $0.02 \mathrm{M}$ were used as the basic gustatory stimuli in the experiment in which receptor potentials were recorded, and the tongue was rinsed with the saline containing $0.041 \mathrm{M} \mathrm{NaCl}$. In the experiment in which impulses were recorded, $0.1 \mathrm{M} \mathrm{NaCl}$, $0.5 \mathrm{M}$ sucrose, $0.01 \mathrm{~N} \mathrm{HCl}$, and $0.02 \mathrm{M}$ quinine $-\mathrm{HCl}$ were used as the basic gustatory stimuli and the tongue was rinsed with water instead of saline for the purpose of recording the large integrated responses to the gustatory stimuli.

Experiments on frogs. A frog, anesthetized with intraperitoneal injection of $5 \%$ urethane or $0.5 \%$ succinylcholine- $\mathrm{Cl}$ Ringer's solution, was fixed on an animal board with a head holder. For recording receptor potentials intracellularly from single gustatory cells, the tongue was pulled out, put into a lucite box, and pinned at the tip onto a plastic plate. Methods used for recording re- 
ceptor potentials were essentially the same as those employed on the rat (OzEKI and SATO, 1972). The glossopharyngeal nerve was cut at a point about $10 \mathrm{~mm}$ from its entry into the tongue and impulses were recorded from the nerve with a technique similar to the one used by YAMASHITA (1964). Solutions used for stimulation of the tongue were $1 \mathrm{M} \mathrm{NaCl}, 0.01 \mathrm{M} \mathrm{CaCl}_{2}$ and $1 \mathrm{M}$ sucrose dissolved in $0.1 \mathrm{M} \mathrm{NaCl}$. After stimulation the tongue was rinsed with saline containing $0.1 \mathrm{M} \mathrm{NaCl}$ and $1.0 \times 10^{-5} \mathrm{M} \mathrm{CaCl}_{2}$.

Of TTX $\left(10^{-6}\right.$ and $\left.10^{-7} \mathrm{~g} / \mathrm{ml}\right)$, procaine- $\mathrm{HCl}(0.1$ and $0.5 \% \mathrm{~W} / \mathrm{V})$ and $\mathrm{ACh}-\mathrm{Cl}$ $\left(10^{-2}-10^{-4} \mathrm{~g} / \mathrm{ml}\right)$ were applied by dissolving them in the stimulating and rinsing solutions.

The experiments were carried out at room temperature, ranging from $20^{\circ} \mathrm{C}$ to $26^{\circ} \mathrm{C}$.

\section{RESULTS}

Effects of tetrodotoxin on the gustatory responses in the rat

Receptor potentials of a rat gustatory cell were recorded by applying $0.3 \mathrm{M}$ $\mathrm{NaCl}$ to the tongue either with or without $10^{-6} \mathrm{~g} / \mathrm{ml}$ TTX. As shown in Fig. 1, $\mathrm{A}$ and $\mathrm{C}$, the receptor potential in response to $0.3 \mathrm{M} \mathrm{NaCl}$ was not inhibited by TTX. Figure 1B indicates that the cell showed scarcely any response to TTX.

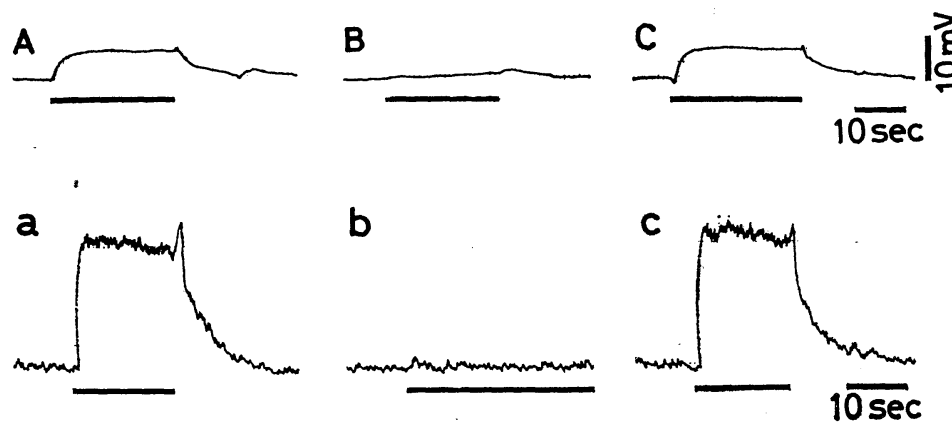

Fig. 1. Receptor potentials in a gustatory cell of fungiform papilla (A, B, and C) and integrated responses of the chorda tympani $(a, b$ and $c)$ of rats. $A$ and $a$ : Control responses to $0.3 \mathrm{M}(\mathrm{A})$ and $0.1 \mathrm{M}$ (a) $\mathrm{NaCl}$. B and $\mathrm{b}$ : Responses to $10^{-6} \mathrm{~g} / \mathrm{ml}$ TTX. $\mathrm{C}$ and $\mathrm{c}$ : Responses to $\mathrm{NaCl}$ with $10^{-6} \mathrm{~g} / \mathrm{ml}$ TTX after soaking the tongue in TTX solution for $5 \mathrm{~min}(\mathrm{C})$ and for half an hour (c). In a and c, rinses with water were followed by off-responses. In this and following figures the signal marker in each record indicates the time of inflow of gustatory stimulus.

The same concentration of TTX also produced no suppression of the receptor potential evoked by $0.5 \mathrm{M}$ sucrose, $0.01 \mathrm{~N} \mathrm{HCl}$, or $0.02 \mathrm{M}$ quinine. The results were similar when studied by recording integrated impulse discharges from the chorda tympani. In that case, TTX elicited no response to the nerve (Fig. 1b). 
Even though the tongue had been soaked in TTX for half an hour, the magnitude of the integrated response induced by $0.1 \mathrm{M} \mathrm{NaCl}$ with TTX remained unchanged, as in the control (Fig. 1,a and c). The magnitudes of integrated responses to $0.5 \mathrm{~m}$ sucrose, $0.01 \mathrm{~N} \mathrm{HCl}$, and $0.02 \mathrm{M}$ quinine were also unaffected by TTX.

\section{Effects of procaine and acetylcholine on the gustatory responses in the rat}

When $0.1 \%$ procaine was applied to the tongue, small receptor potentials were recorded intracellularly from single gustatory cells (Fig. 2Bb). The same concentration of procaine also induced small integrated responses (Fig. 2Ba).

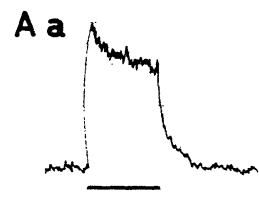

b

B a

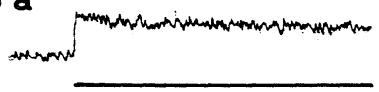

C a

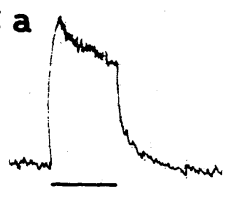

b

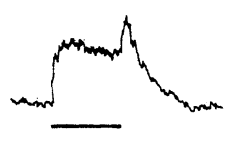

c
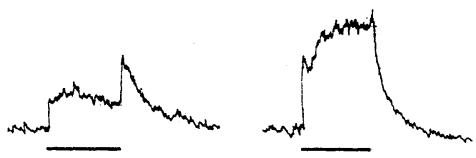

b

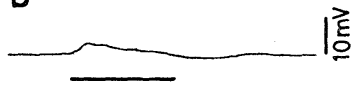

c

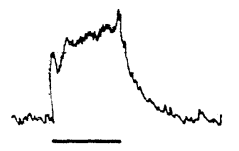

d

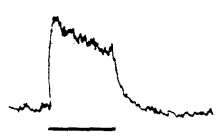

$\mid \overrightarrow{\underline{E}}$

d

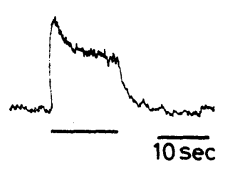

Fig. 2. Effects of procaine- $\mathrm{HCl}(0.1 \%)$ on integrated response of chorda tympani (A, $\mathrm{Ba}$, and $\mathrm{C}$ ) and receptor potential $(\mathrm{Bb})$ in the rat. $\mathrm{A}$ : Control responses to four basic gustatory qualities. B: Responses of chorda tympani (a) and receptor potential of a gustatory cell (b) to $0.1 \%$ procaine. C: Responses to the four gustatory qualities applied with $0.1 \%$ procaine, obtained after soaking in procaine for half an hour. Aa and $\mathrm{Ca}$ : Responses to $0.1 \mathrm{M} \mathrm{NaCl}$. $\mathrm{Ab}$ and $\mathrm{Cb}$ : Responses to $0.5 \mathrm{~m}$ sucrose. $\mathrm{Ac}$ and $\mathrm{Cc}$ : Responses to $0.01 \mathrm{~N} \mathrm{HCl}$. Ad and $\mathrm{Cd}$ : Responses to $0.02 \mathrm{~m}$ quinine.

The $\mathrm{pH}$ of $0.1 \%$ procaine solution was neutral. After the tongue had been soaked in $0.1 \%$ procaine for half an hour, as in the previous TTX experiment, the magnitude of integrated responses to $0.1 \mathrm{M} \mathrm{NaCl}$ and $0.02 \mathrm{M}$ quinine did not change, while the response to sucrose increased slightly and that to $\mathrm{HCl}$ decreased (Fig. 2, A and C). After the tongue had been rinsed with water the magnitude of the integrated responses to sucrose and $\mathrm{HCl}$ recovered. A higher concentration of procaine, such as $0.5 \%$, also did not block gustatory nerve responses.

The gustatory cells showed hardly any potential change in response to $10^{-4} \mathrm{~g} / \mathrm{ml}$ ACh conforming to the report by TATEDA and BEIDLER (1964). However, $10^{-3} \mathrm{~g} / \mathrm{ml}$ ACh evoked small responses in both the cell and the nerve, but it did not modify gustatory responses to any applied stimulants. 
The results described in this and preceding sections seem to indicate that TTX, procaine, and ACh do not affect the primary activity of gustatory cells nor they diffuse into the space surrounding gustatory cells and therefore do not affect the activity of intragemmal fibers.

\section{Effects of tetrodotoxin on the responses to $\mathrm{NaCl}$ and $\mathrm{CaCl}_{2}$ in the frog}

As in the rat, $10^{-6} \mathrm{~g} / \mathrm{ml}$ TTX neither produced any potential change in the frog gustatory cell nor inhibited the generation of receptor potential in response to $1 \mathrm{M} \mathrm{NaCl}$ (Fig. 3). When TTX dissolved in $0.1 \mathrm{M} \mathrm{NaCl}$ was applied to the tongue, no obvious discharge of nerve impulses could be observed except for a

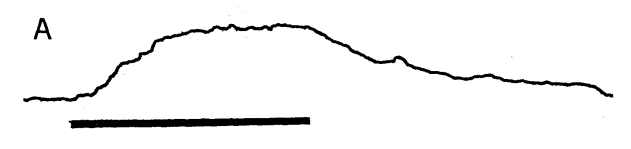

B

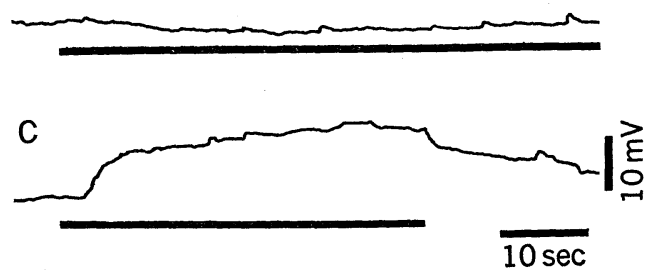

Fig. 3. Receptor potentials of a gustatory cell in fungiform papilla of frog. A: Control response to $1 \mathrm{M} \mathrm{NaCl}$. B: Response to $10^{-6} \mathrm{~g} / \mathrm{ml}$ TTX dissolved in the saline. C: Response to $1 \mathrm{M} \mathrm{NaCl}$ with $10^{-6} \mathrm{~g} / \mathrm{ml}$ TTX after soaking the tongue in TTX solution for $6 \mathrm{~min}$.

small transient response (Fig. 4B). The magnitude of the integrated response to $1 \mathrm{M} \mathrm{NaCl}$ containing TTX was not different from that produced by $\mathrm{NaCl}$ alone immediately after the application of TTX, however, within a few minutes, it became considerably smaller than the control. After half an hour in TTX, the response to $1 \mathrm{M} \mathrm{NaCl}$ decreased to about one half of the control (Fig. 4C). In two frogs the magnitudes of the responses to $1 \mathrm{M} \mathrm{NaCl}$ were depressed to 43 and $67 \%$ of the control by application of TTX for half an hour. It lasted for 20 to $30 \mathrm{~min}$ to recovery to the original response magnitude (Fig. 5).

The response to $0.01 \mathrm{M} \mathrm{CaCl}_{2}$ studied in two frogs was also depressed in magnitude to 60 and $69 \%$ of the control after immersion of the tongue in TTX for half an hour. When the tongue was rinsed by the saline, the response to $0.01 \mathrm{M} \mathrm{CaCl}_{2}$ gradually recovered to the control value (Fig. 5).

This may indicate that TTX, while little affecting the responses of gustatory cell, but would diffuse into the intercellular space of fungiform papillae of the 
frog and block the excitation in some of the intragemmal fibers which are probably located near the tongue surface, leaving deeply located fibers unaffected.

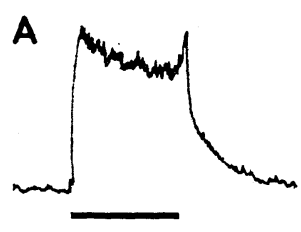

C

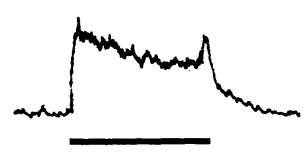

B

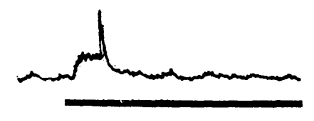

D

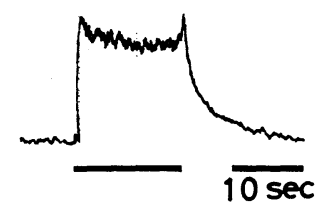

Fig. 4. Integrated responses of the glossopharyngeal nerve of frog. A: Response to $1 \mathrm{M} \mathrm{NaCl}$. B: Response to $10^{-6} \mathrm{~g} / \mathrm{ml}$ TTX dissolved in the saline. C: Response to $1 \mathrm{M} \mathrm{NaCl}$ after soaking the tongue in TTX for half an hour. D: Response to $1 \mathrm{M}$ $\mathrm{NaCl}$ after TTX was washed out for half an hour.

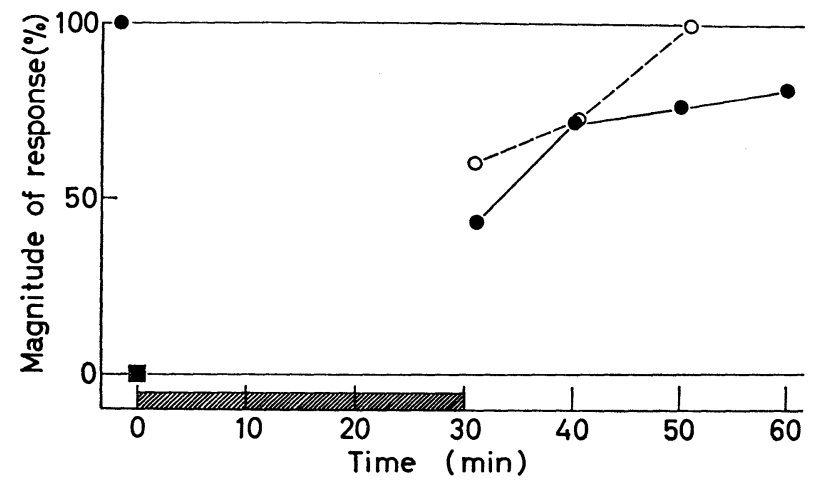

Fig. 5. Time course of recovery from the effect of $10^{-6} \mathrm{~g} / \mathrm{ml}$ TTX as observed in the integrated response to $1 \mathrm{M} \mathrm{NaCl}$ (filled circles) and $0.01 \mathrm{M} \mathrm{CaCl}_{2}$ (open circles) in the glossopharyngeal nerve of frogs. The shaded horizontal bar indicated the period when the tongue was soaked in the saline containing TTX. The filled square at zero time indicated the response to $10^{-6} \mathrm{~g} / \mathrm{ml} \mathrm{TTX}$.

Effect of procaine and acetylcholine on the response to $\mathrm{NaCl}$ in the frog

When $0.5 \%$ procaine was applied to the tongue, small transient integrated responses could be recorded. After immersion of the tongue in the same concentration of the procaine for half an hour, the magnitudes of the integrated responses to $1 \mathrm{M} \mathrm{NaCl}$ were decreased to $5 \%$ or less. This responses to $\mathrm{NaCl}$ gradual- 
ly returned to the original value after the tongue was rinsed with the saline.

Application of $10^{-3} \mathrm{~g} / \mathrm{ml} \mathrm{ACh}$ to the tongue produced no obvious response in gustatory cells and in the nerves. However, after the tongue had been soaked for $10 \mathrm{~min}$ in saline containing the same amount of $\mathrm{ACh}$, the magnitude of integrated response to $1 \mathrm{M} \mathrm{NaCl}$ increased gradually up to $160 \%$ of the control value. This is similar to the report by LANDGREN, et al. (1954), who showed that the presence of $\mathrm{ACh}$ increased the sensitivities of the response to tap water and $\mathrm{NaCl}$. After the tongue had been rinsed with saline, the magnitude of the integrated response to $\mathrm{NaCl}$ returned to the original value. When the tongue had been soaked for $18 \mathrm{~min}$ in $10^{-2} \mathrm{~g} / \mathrm{ml} \mathrm{ACh}$, the magnitude of integrated response to $0.5 \mathrm{M} \mathrm{NaCl}$ decreased to as little as $6 \%$ of the control value, probably by a paralytic effect resulting from depolarization in a great extent caused by an excess amount of ACh on synaptic transmission (KATZ and THESLEFF, 1957). The responses to sucrose and to water were also depressed by high concentration of ACh.

The results seem to indicate that ACh and procaine, like TTX, can slowly diffuse into the intercellular space in the fungiform papillae of frog.

\section{DISCUSSION}

KATSUKI et al. $(1970,1971)$ have reported on the lateral-line organs of mullet and catfish that TTX suppressed chemoreception of monovalent cations such as $\mathrm{K}$ and $\mathrm{Na}$ ions but that the drug did not produce any suppressing action on the chemoreception of $\mathrm{Ca}$ ion by the same organ of catfish. In the gustatory receptor of frog and rat, the present study confirmed that TTX does not suppress the receptive process taking place in the microvillous membrane of the gustatory cells. It can thus be assumed that the primary gustatory processes in frog and rat are different from the primary chemoreceptive process taking place in the lateral-line organ of fish.

TATEDA and BeIDLER (1964) demonstrated in the rat that $1 \%$ cocaine applied to the tongue surface elicited a large depolarizing response in the gustatory cell and also inhibited the neural response to the chemical stimuli recorded from the chorda tympani nerve. However, it was shown in the present study that, despite its small depolarizing action on the gustatory cell, procaine at 0.1 to $0.5 \%$, which was more than enough to block the conduction when it was applied directly to the nerve, did not inhibit the generation of the receptor potential and the nerve impulses in response to gustatory stimulation.

The generation of receptor potentials in response $\mathrm{NaCl}$ and $\mathrm{CaCl}_{2}$ was not suppressed for several min by TTX in gustatory cell of the frog, while the neural response was considerably depressed. Similarly, a soaking of the tongue in concentrated ACh solution was found to modify the neural response. Hence it may be assumed that the composition of the fluid in the intercellular space of the frog gustatory cells where some of afferent nerve endings were present can be slightly 
modified by applying different solutions over the tongue surface. Cocaine $\left(10^{-3} \mathrm{~g} / \mathrm{ml}\right)$ also abolished the neural response to any gustatory stimuli in the frog (KuSANO, 1959).

In the rat, on the other hand, TTX, procaine and ACh applied to the tongue surface could not modify the neural response to gustatory stimuli. Thus the possibility of penetration of such drugs into the space surrounding the gustatory cells would be negligibly small. The reasoning is supported by morphological findings, for an extensive fusion of the outer lamellae of the plasma membrane of adjacent cells is observed over the distal end of the fungiform papilla of the rat (FARBMAN, 1965). Furthermore, in circumvallate papilla of the rat, a sealing off of the extracellular spaces against the outside is observed at the neck of the gustatory cells (GRAY and WATKINS, 1965). It has been shown that colchicine had no effect when applied to the surface of tongue of the rat but it blocked mitotic division of the epithelial cells of the tongue when injected intraperitoneally (BEIDLER and Smallman, 1965). This finding may also indicate that colchicine could not enter the space between the taste cells when applied to the tongue surface.

The difference between the effects of TTX, procaine and ACh on the tongue of frog and that of rat might derive from the morphological diferences. If this is the case, it may be predicted that, when the frog tongue is rinsed with the saline after a stimulation by gustatory stimulating solutions, its recovery to the normal responses requires a long period.

We thank Prof. M. Sato for his valuable advices and for reading the manuscript. This work was supported by a grant from the Education Ministry of Japan.

\section{REFERENCES}

Beidler, L. M. and Smallman, R. L. (1965) Renewal of cells within taste buds. J. cell. Biol., 27: $263-272$.

FARBMAN, A. I. (1965) Electron microscope study of the developing taste bud in rat fungiform papilla. Develop. Biol., 11: 110-135.

Furukawa, T., Sasaoka, T., and Hosoya, Y. (1959) Effects of tetrodotoxin in the neuromuscular junction. Jap. J. Physiol., 9: 143-152.

Gray, E. G. and WATkins, K. C. (1965) Electron microscopy of taste buds of the rat. $Z$. Zellforsch., 66: 583-595.

Katsuki, Y., Hashimoto, T., and Kendall, J. I. (1971) The chemoreception in the lateralline organs of teleosts. Jap. J. Physiol., 21: 99-118.

Katsuki, Y., Hashimoto, T., and Yanagisawa, K. (1970) The lateral-line organ of shark as a chemoreceptor. Adv. Biophys., 1: 1-51.

KATZ, B. and THESLEFF, S. (1957) A study of the 'desensitization' produced by acetylcholine at the motor end-plate. J. Physiol., 138: 63-80.

KusANO, K. (1959) The influence of narcotics on the activity of gustatory receptors. Kumamoto Med. J., 12: 236-243.

Landgren, S., Liljestrand, G., and Zotterman, Y. (1954) Chemical transmission in taste fibre endings. Acta Physiol. Scand., 30: 105-114.

Narahashi, T., Moore, J. W., and ScOTt, W. R. (1964) Tetrodotoxin blockage of sodium 
conductance increase in lobster giant axons. J. Gen. Physiol., 47: 965-974.

ONODA, N. and KATSUKI, Y. (1972) Chemoreception of the lateral-line organ of an aquatic amphibian, Xenopus laevis. Jap. J. Physiol., 22: 87-102.

Ozeki, M., Freeman, A. R., and Grundfest. H. (1966) The membrane components of crustacean neuromuscular systems. I. Immunity of different electrogenic components to tetrodotoxin and saxitoxin. J. Gen. Physiol., 49: 1319-1334.

OzeKi, M. and SATo, M. (1972) Responses of gustatory cells in the tongue of rat to stimuli representing four taste qualities. Comp. Biochem. Physiol., 41A: 391-407.

TAtedA, H. and Beidler, L. M. (1964) The receptor potential of the taste cell of the rat. $J$. Gen. Physiol., 47: 479-486.

YAMASHITA, S. (1964) Chemoreceptor response in frog, as modified by temperature change. Jap. J. Physiol., 14: 488-504.

YAMASHitA, S. and SATO, M. (1965) The effects of temperature on gustatory response of rats. Jap. J. Physiol., 66: 1-18. 